\title{
DESACATO À SANTÍSSIMA EUCARISTIA: O DEVANEIO DE JOANA MARIA NO GRÃO-PARÁ (1771-1774)
}

\section{CONTEMPT FOR THE BLESSED EUCHARIST: THE DAYDREAM OF JOANA MARIA IN GRÃO-PARÁ (1771-1774)}

Ronaldo Manoel Silva ${ }^{53}$

\begin{abstract}
Resumo: O objetivo deste artigo é analisar o processo inquisitorial da jovem Joana Maria, implicada em sacrilégio à Santíssima Eucaristia após a última visitação do Santo Ofício ao Brasil no Estado do Grão-Pará. Por determinação do Vigário Capitular do bispado, Geraldo José de Abranches, Joana foi enviada ao Tribunal da Inquisição de Lisboa para responder por seu crime. Dentre as tantas conclusões possíveis, estamos convencidos de que Joana recorreu a esse delito para alcançar uma nova perspectiva de futuro.
\end{abstract}

Palavras-chave: Estado do Grão-Pará; Tribunal da Inquisição; Eucaristia.

\begin{abstract}
The objective of this article is to analyze the inquisitorial process of the young Joana Maria, implicated in sacrilege to the Holy Eucharist after the last visit of the Holy Office to Brazil in the State of Grão-Pará. By determination of the Vicar Chapter of the bishopric, Geraldo José de Abranches, Joana was sent to the Lisbon Inquisition Court to answer for his crime. Among the many possible conclusions, we are convinced that Joana resorted to this crime to reach a new perspective of the future.
\end{abstract}

Keywords: State of Grão-Pará; Court of the Inquisition; Eucharist.

\section{A Inquisição na Era Pombalina}

A 21 de março de 1759, tomava posse como deputado do Conselho Geral do Santo Ofício, Paulo de Carvalho e Mendonça (irmão de Sebastião José de Carvalho e Melo, o marquês de Pombal). O novo ministro nunca servira na Inquisição, sequer como deputado de uma Mesa distrital. Com o rompimento das relações diplomáticas entre a Coroa e a Sé Apostólica - devido a expulsão dos jesuítas de Portugal e suas colônias - e a renúncia do inquisidor-geral, D. José de Bragança (em 1760), iniciouse um período em que durante quase dez anos o Santo Ofício ficou sem inquisidorgeral. Em janeiro de 1766, os deputados do Conselho Geral instituíram Paulo de

${ }^{53}$ Mestre em História pela UFRPE

REHR | Dourados, MS | v. 13 | n. 25 | p. 76-92 | Jan. / Jun. 2019 


\section{HISTÓRIA \\ MUNDO LUSO BRASILEIRO: RELAÇÕES DE PODER E RELIGIÃO}

Carvalho e Mendonça como Inquisidor da Corte (conferindo-Ihe capacidade para julgar qualquer causa inquisitorial em Lisboa, ou onde residisse o Conselho). $\mathrm{Na}$ prática, Carvalho e Mendonça governava o Santo Ofício como se fosse inquisidorgeral (MARCOCCI; PAIVA, 2013, p. 338-342; 348).

Em abril de 1768, um decreto régio criou a Real Mesa Censória, que passava a ter jurisdição exclusiva sobre a censura e circulação de livros no Reino. A nova instância, embora não eliminasse, diminuía significativamente o poder censório do Santo Ofício. O projeto do marquês de Pombal não era liquidar a Inquisição, mas submetê-la aos interesses da Coroa. Um alvará de 1769 equiparou o Santo Ofício a qualquer outro tribunal régio e com a reabertura da diplomacia com a Sé Apostólica, D. João Cosme da Cunha (um dos mais submissos aliados das políticas pombalinas) tomou posse com inquisidor-geral em 1770. Uma decisão de Pombal, com grande impacto para a Inquisição, foi a carta-lei de 1773, que pôs fim à distinção entre cristãos-velhos e cristãos-novos. Na sequência, articulou a elaboração de um novo Regimento inquisitorial. A proposta foi apresentada pelo Conselho Geral ao rei em julho de 1773 e, após concluído, o Regimento foi aprovado em setembro de 1774. Ainda em 1774, o marquês enviou missiva ao governador da Índia (José Pedro da Câmara), informando a extinção da Mesa de Goa (ibid., p. 346-353; 413).

É nessa conjuntura política - de enfraquecimento do poder da Inquisição e de sua gradativa submissão aos interesses da Coroa - que se dá a última visitação do Santo Ofício ao Brasil no Estado do Grão-Pará (1763-1769). Por certo, para além das questões religiosas que seriam levantadas, a visitação tinha o objetivo de atuar numa região estratégica do território brasílico e extirpar da população local qualquer influência dos jesuítas que ainda resistisse. O escolhido pelo Conselho Geral, a 21 de junho de 1763, para encabeçar tal missão foi Geraldo José de Abranches, inquisidor de Évora.

Geraldo José de Abranches nasceu em 1711, na freguesia de Nossa Senhora da Natividade de Vila Cova de Sub-Avô (bispado de Coimbra), era filho de Antônio Martins da Costa e Brígida de Abranches. Entre 1731 e 1738, tornou-se bacharel e licenciado em Cânones pela Universidade de Coimbra. Era sacerdote do hábito de São Pedro. Foi nomeado, em 1746, provisor, arcipreste e vigário-geral do bispado de São Paulo. Também foi nomeado secretário da Bula da Cruzada e, antes de 


\section{HISTOERIA \\ MUNDO LUSO BRASILEIRO: RELAÇÕES DE PODER E RELIGIÃO}

embarcar para o Brasil, passou por Lisboa habilitando-se a comissário do Santo Ofício, o que conseguiu em janeiro de 1747. Após desentendimentos com o bispo de São Paulo, D. Bernardo Rodrigues Nogueira, partiu para a diocese de Mariana onde foi nomeado arcediago e, poucos dias depois, vigário-geral do bispado. Desentendimentos com o bispo, D. Frei Manuel da Cruz, o fizeram regressar a Lisboa (1752). Em 1760, foi nomeado deputado e, em seguida, promotor da Inquisição de Coimbra. A 3 de março de 1761 foi promovido a inquisidor de Évora (BRAGA, 2006, p. 253-269).

Não permaneceu por muito tempo em Évora, sendo nomeado em 1763 a visitador do Santo Ofício ao Grão-Pará (incluindo as capitanias do Maranhão, Rio Negro e Piauí). A visitação inicialmente foi tensa, pois o vigário-geral (Pedro Barbosa Canais) acusou o bispo, o beneditino D. Frei João de São José Queirós, de tentar obstruir a ação de um comissário inquisitorial. Embora tal denúncia não conste no livro da visita, o monarca ordenou que o prelado voltasse ao Reino. Geraldo José de Abranches passa então a cumular as funções de visitador inquisitorial e Vigário Capitular do bispado (até que fosse nomeado um novo bispo). A visitação se estendeu até 1769, com o seguinte número de denunciantes: 22 em 1763; 11 em 1764; três em 1765, seis em 1766; um em 1767 e, finalmente, dois em 1769. Contudo, concluída a visitação, José de Abranches não deixou o Pará. Permaneceu em Belém, na função de Vigário Capitular, até o final de 1772 (ou início de 1773), aguardando a chegada do novo bispo D. Frei João Evangelista Pereira (BRAGA, loc. cit.).

\section{A última visitação}

A sociedade do Pará vivia certo desregramento dos costumes religiosos, ainda quando a região estava sob a influência dos jesuítas. Ao uso da aguardente, eram atribuídos os excessos praticados inclusive por muitos religiosos. Esses abusos eram tão frequentes que, em 1748, o rei ordenou ao governador que interrompesse a fabricação da aguardente. Os comerciantes eram, constantemente, acusados de roubar nos pesos e medidas; e de arbitrarem preços abusivos. Em 1757, uma carta régia determinou que nas capitanias de Belém do Grão-Pará, São 


\section{HISTÓRIA}

\section{MUNDO LUSO BRASILEIRO: RELAÇÕES DE PODER E RELIGIÃO}

Luís do Maranhão e São José do Rio Negro, as câmaras conservassem pesos e medidas para servirem de padrão geral. Os crimes de natureza sexual, sobretudo de brancos em relação às índias, eram muito comuns. $O$ aljube eclesiástico vivia cheio de presos, particularmente índios e escravos, sendo as mulheres em maior número (LIVRO DA VISITAÇÃO DO SANTO OFÍCIO..., 1978, p. 30-31).

Por ocasião da visitação, a cidade de Belém devia contar com uma população entre nove e dez mil habitantes. A 25 de setembro de 1763, ocorreu a soleníssima procissão que saiu da igreja de Nossa Senhora das Mercês, acompanhada pelas autoridades eclesiásticas e civis, à Catedral. O inquisidor seguia debaixo de um pálio. Concluída a procissão, celebrou-se missa solene cantada, durante a qual o visitador permaneceu sentado numa cadeira de espaldar sobre alcatifa, com almofada de veludo aos pés, ao lado do Evangelho. O bispo, ainda no cargo, permaneceu na cátedra acompanhado do diácono e subdiácono. O Sermão da Fé foi pregado pelo Frei Pedro Mendes (religioso de Nossa Senhora das Mercês). Em seguida, foram publicados os Éditos da Fé e da Graça, e o Monitório Geral - tinha início o tempo da graça. Na sequência, de joelhos diante do inquisidor, as autoridades civis e todo o povo fizeram o Juramento da Fé e enteou-se o Te Deum. Por fim, o notário se dirigiu à fixação, nas portas do templo, dos éditos e alvará que ali permaneceram pelos próximos 30 dias (ibid., p. 38; 51-53).

O visitador ouviu diversas denúncias de ações desumanas e atos ofensivos ao sagrado; conheçamos alguns casos: conforme o relato de Romão Lourenço, a 18 de maio de 1764, a jovem Ana (12 anos de idade), filha de José Antônio Moreira e Joana Maria, moradora na Ilha do Marajó, na casa do capitão-mor José Miguel Ayres, sofreu diversos maus tratos por não terminar "de fiar sua tarefa de algodão". Trancada num quarto, "ficando ela com os braços em cruz, em pé, e com ambos os pés juntos, sem poder bulir com os pés nem com as mãos". Dessa forma foi mantida presa de manhã até a noite. Quando foram soltá-la, "não podia mover-se, nem ser senhora de alguma ação natural dos seus membros”. Noutra ocasião, foi presa numa cruz de Santo André. Ana descreveu ainda, os "horríveis desacatos" que os dois filhos de André Miguel Ayres faziam diante de um oratório: cuspiam no crucifixo e nas imagens dizendo nomes injuriosos "como hipócritas, judeu [...] [e] desabotoando os calções, levantavam a camisa pela parte detrás e viravam esta 


\section{HISTÓRIA \\ MUNDO LUSO BRASILEIRO: RELAÇÕES DE PODER E RELIGIÃO}

parte para as ditas imagens, e abrindo as nádegas [as] mostravam, olhando ao mesmo tempo com o rosto torcido" (ANTT, IL, proc. 13.327, fls. 2-5).

Em 26 de agosto de 1765, Luís de Sousa Silva denunciou o companheiro de desdita (na enxovia da cadeia pública) Francisco José, por proferir blasfêmias afirmando "que não há Deus, e que o Deus que há o pisa debaixo dos pés. [...] Porque Deus não tinha poder algum e somente o tinha o Diabo". Francisco não costumava ouvir missa; quando o sacerdote a celebrava num altar (defronte a cadeia), virava as costas dando gargalhadas. Noutras vezes, cometia "o abominável pecado de molície" (masturbação) enquanto se celebrava o Santo Sacrifício da Missa e "atrevidamente o fazia em qualquer hora que the parecia, dizendo e afirmando que aquilo não era pecado". Quando os prisioneiros o advertiam que, segundo São Paulo, aquelas "poluções procuradas [...] eram pecados", respondia que São Paulo "era um bêbado, um asno, que não sabia o que dizia". Francisco nunca rezava o terço (à noite com os outros detentos) e quando os colegas iam beijar os pés da imagem do Senhor Crucificado, ele dizia que a tirassem da sua frente "e a metessem na parte mais imunda do corpo humano" (ANTT, IL, proc. 219, fls. 62-65).

Abusos sexuais de escravos também foram relatados. Em 10 de junho de 1767, o preto Joaquim Antônio procurou a Mesa da visitação para denunciar seu senhor Francisco Serrão de Castro. Certa vez - forçado e com medo -, foi vítima de conatus: "com as costas para cima", seu senhor tentava penetrá-lo pelo vaso preposterum, "o que não podendo ele confitente tolerar, se sacudiu como pôde, sem que pudesse o dito [Francisco] consumar o seu depravado apetite, senão fora do dito vaso, enchendo-Ihe as pernas do sêmen que derramou". Francisco Serrão de Castro forçava diversos escravos à sodomia, muitos deles depois de violentados ficavam "inchados na via do curso, e lançando sangue". Os cativos Pedro, Manoel Fagundo e Antônio (da nação Mixicongo), se queixavam "de Ihes ter feito o dito Francisco Serrão de Castro aquelas inchações e infusões de sangue com o seu membro". Por "esta causa morreram" alguns escravos pois, "logo depois dos ditos atos e das ditas inchações adoeceram, até que acabaram [suas] vidas" (ANTT, IL, proc. 12.894 , fls. $2-5 \mathrm{v})$. 


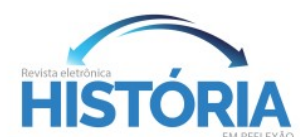

\section{MUNDO LUSO BRASILEIRO: RELAÇÕES DE PODER E RELIGIÃO}

Geraldo José de Abranches instaurou muitos processos contra homens e mulheres implicados nos mais diversos crimes. Antes, porém, de adentrarmos na análise do objeto desta pesquisa, é oportuno saber que ilícitos femininos foram reprimidos pela Mesa inquisitorial. Efetivamente, nove mulheres foram processadas pelo visitador: quatro por bigamia, duas feiticeiras, uma por práticas supersticiosas, uma por proposições heréticas e uma por sodomia imperfeita. Seis foram sentenciadas, duas faleceram no cárcere antes da sentença. As faixas etárias eram variadas, assim como as ocupações. Todas elas pertenciam às classes baixas da sociedade, do ponto de vista financeiro. São processos interessantíssimos, entretanto, nossa atenção se voltará para um caso pós-visitação (enquanto o Vigário Capitular aguardava a chegada do novo bispo). O sacrilégio de Joana Maria (19 anos de idade), casada com Francisco Antônio, gerou grande comoção social e exigiu uma punição exemplar.

Quadro 1: Mulheres processadas na visitação do Grão-Pará

\begin{tabular}{|c|c|c|c|c|c|c|}
\hline Processo & Ré & Idade & Ocupação & Crime & Sentença & $\begin{array}{c}\text { Data da } \\
\text { sentença }\end{array}$ \\
\hline 210 & $\begin{array}{l}\text { Maria } \\
\text { Francisca }\end{array}$ & 20 anos & Escrava & Superstição & $\begin{array}{l}\text { Asperamente } \\
\text { repreendida e } \\
\text { admoestada para não } \\
\text { reincidir em } \\
\text { superstições }\end{array}$ & $11 / 10 / 1768$ \\
\hline 222 & Rosaura & 36 anos & --- & Bigamia & $\begin{array}{l}\text { Admoestada para que } \\
\text { voltasse com seu } \\
\text { primeiro marido }\end{array}$ & $11 / 10 / 1768$ \\
\hline 225 & $\begin{array}{l}\text { Florência } \\
\text { Martins }\end{array}$ & 28 anos & --- & Bigamia & $\begin{array}{l}\text { Admoestada para que } \\
\text { voltasse com seu } \\
\text { primeiro marido }\end{array}$ & $11 / 10 / 1768$ \\
\hline 2.691 & $\begin{array}{l}\text { Joana } \\
\text { Maria }\end{array}$ & 23 anos & Escrava & Feitiçaria & $\begin{array}{l}\text { Abjuração de levi, } \\
\text { instrução na fé } \\
\text { católica, penitências } \\
\text { espirituais }\end{array}$ & $30 / 05 / 1768$ \\
\hline 2.699 & $\begin{array}{l}\text { Maria } \\
\text { Teresa }\end{array}$ & 50 anos & --- & Bigamia & $\begin{array}{l}\text { A 13/06/1767, a ré } \\
\text { faleceu no cárcere } \\
\text { sem ter sido } \\
\text { sentenciada }\end{array}$ & --- \\
\hline 2.703 & $\begin{array}{l}\text { Escolásti } \\
\text { ca Benta }\end{array}$ & 55 anos & Criada & Bigamia & $\begin{array}{l}\text { A 13/12/1772, a ré } \\
\text { faleceu no cárcere, } \\
\text { sem ter sido } \\
\text { sentenciada }\end{array}$ & --- \\
\hline 2.704 & $\begin{array}{l}\text { Joana de } \\
\text { Azevedo }\end{array}$ & 37 anos & --- & $\begin{array}{c}\text { Proposições } \\
\text { heréticas }\end{array}$ & --- & --- \\
\hline 2.705 & $\begin{array}{l}\text { Dominga } \\
\text { s Gomes } \\
\text { da }\end{array}$ & 50 anos & --- & Feitiçaria & $\begin{array}{l}\text { Abjuração de levi, } \\
\text { instrução na fé } \\
\text { católica, penitências }\end{array}$ & $07 / 01 / 1764$ \\
\hline
\end{tabular}

REHR | Dourados, MS | v. 13 | n. 25 | p. 76-92 | Jan. / Jun. 2019 


\section{HISTÓRIA}

MUNDO LUSO BRASILEIRO: RELAÇÕES DE PODER E RELIGIÃO

\begin{tabular}{|c|l|l|l|l|l|l|}
\hline & $\begin{array}{l}\text { Ressurrei } \\
\text { ção }\end{array}$ & & & & espirituais & \\
\hline $\mathbf{2 . 7 0 7}$ & $\begin{array}{l}\text { Feliciana } \\
\text { de Lira } \\
\text { Barros }\end{array}$ & 36 anos & Costureira & $\begin{array}{l}\text { Sodomia } \\
\text { imperfeita }\end{array}$ & $\begin{array}{l}\text { Admoestada a não } \\
\text { reincidir, penitências } \\
\text { espirituais }\end{array}$ & 23/01/1764 \\
\hline
\end{tabular}

"Ó céus, pasmai, tremei de espanto e horror"

Era uma tarde ensolarada e quente na pequena Vila Vistosa da Madre de Deus (bispado do Grão-Pará), 5 de novembro de 1771, o vigário Brás João Romeiro estava na porta da Igreja Matriz quando, apressadamente, Joana Maria se dirigiu ao religioso com um semblante atemorizado e Ihe apresentou uma hóstia sobre um pedaço de papel. Ainda confuso, padre João Romeiro pegou na mão a partícula quando o sargento-mor D. João Henriques Souto Maior, que via a cena, esbravejou: "É esta, a moça!". O clérigo imediatamente recordou-se que naquela manhã ouvira Joana em confissão e, em seguida, a mesma assistiu o Santo Sacrifício da Missa ocasião em que Ihe administrou a sagrada comunhão. Ao que parece, a denúncia era verdadeira. O vigário ordenou então que Joana fosse detida na cadeia da vila, "com ferros nos pés, presa a um tronco".

Imediatamente os boatos se proliferaram: "Joana é uma feiticeira!" - diziam alguns. "Tentou vender uma partícula consagrada para ganhar dinheiro" - afirmavam outros. Inclusive, correu a notícia de que a moça deixara a hóstia na casa de uma vizinha e esta, por sua vez, havia preparado um altar para adoração em sua residência e já cogitava organizar uma procissão que acompanharia o retorno da partícula consagrada para o sacrário da matriz. A notícia rapidamente chegou aos ouvidos do Vigário Capitular que delegou o padre Inácio José Pastana (reitor do seminário) que fosse a Vila Vistosa e analisasse o sumário elaborado pelo padre Brás João Romeiro. A 19 de novembro (1771), José Pastana entregou o sumário a José de Abranches afirmando que a dita "Joana Maria, após comungar, extraiu da boca a sagrada partícula e embrulhou-a numa folha de mato com a intenção de vendê-la por oito vinténs". Dada a gravidade das denúncias (feitas por cinco testemunhas), o reitor aconselhou que a delata fosse remetida ao Tribunal do Santo Ofício. 


\section{HISTÓRIA \\ MUNDO LUSO BRASILEIRO: RELAÇÕES DE PODER E RELIGIÃO}

No mesmo dia, José de Abranches ordenou que Joana fosse trazida presa para Belém e delegou o padre Jerônimo Álvares de Carvalho para ratificar as testemunhas do sumário e ouvir novos delatores. Em 10 de dezembro, padre Álvares de Carvalho concluiu um novo sumário que contava com relatos de nove testemunhas e todas confirmaram as acusações. Joana Maria ofendera o que havia de mais sagrado na Igreja. O Concílio Ecumênico de Trento, no Decreto sobre a Santíssima Eucaristia, tratou longamente do mistério eucarístico e da excelência da Eucaristia sobre os outros sacramentos, por ser a forma visível da graça invisível. Nela está o próprio autor da santidade; depois da consagração estão o verdadeiro corpo de Nosso Senhor e seu verdadeiro sangue conjuntamente com sua alma e sua divindade, o Cristo todo inteiro está sob a espécie de pão e sob a mínima parte dessa espécie; bem como sob a espécie de vinho e sob qualquer das partes dessa espécie (CONCÍLIO ECUMÊNICO DE TRENTO, Sessão XIII, de 11 de outubro de 1551).

O Decreto tridentino também esclarecia em que situações se deveria excomungar os que atentavam contra o mistério eucarístico: quem negar a presença real de Cristo na Eucaristia e disser que se trata apenas de um símbolo do seu corpo; quem negar a transubstanciação; quem negar que está presente o Cristo todo inteiro sob as espécies consagradas e sob cada parte dessas espécies quando se dividem; quem afirmar que o verdadeiro corpo do Senhor não permanece nas partículas que se guardam no tabernáculo; quem negar que o principal fruto da Eucaristia é a remissão dos pecados; quem afirmar que não se deve adorar o Santíssimo Sacramento; quem negar que se deve comungar ao menos na Páscoa da Ressurreição. E, para que não se receba indignamente tão grande sacramento, quem estiver em pecado mortal (ainda que arrependido), está obrigado a procurar um confessor e primeiro fazer sua confissão (CONCíLIO ECUMÊNICO DE TRENTO, loc. cit.).

Desnecessário dizer que as diretivas conciliares eram amplamente conhecidas pelo clero e difundidas entre o povo. Era raro que alguém desacatasse o Santíssimo Sacramento; haveria de ter uma motivação muito forte para isso. Joana Maria foi ouvida duas vezes na cadeia de Belém pelo próprio José de Abranches e, sem hesitar, confirmou as denúncias: desejava vender a hóstia consagrada qual 


\section{HISTÓRIA}

\section{MUNDO LUSO BRASILEIRO: RELAÇÕES DE PODER E RELIGIÃO}

"relíquia do Santo Lenho, ou um Agnus Dei [sic]". O sacrilégio de Joana, causou espanto, horror e uma grande comoção popular. Em desagravo "ao Senhor, no mesmo Sacramento ofendido", o Vigário Capitular publicou um edital determinando a realização de um tríduo com fervorosas preces e adoração a Jesus Eucarístico: para "fazermos digna da sua aceitação a nossa humilde, reverente, devota e pia ação de graças".

Com este sensibilíssimo assunto, ordenei por um edital, se fizessem preces por três dias nas igrejas desta cidade, e bispado, com a exposição e bênção do Santíssimo Sacramento; e no terceiro [dia] procissão geral com o mesmo Santíssimo Sacramento, concedendo por Autoridade e Delegação Apostólica, indulgência plenária a todas as pessoas que com as circunstâncias expressas no referido edital visitasse nesta cidade a Igreja Catedral (AHU, Pará, Cx. 67, doc. 5.805).

O tríduo ocorreu entre 20 e 22 de dezembro (1771). Na tarde do dia 22, houve um longo sermão sobre o mistério eucarístico e, em seguida, saiu da catedral de Belém o Vigário Capitular e uma solene procissão com o Corpo de Deus. Uma salva de toda a artilharia - "ao Divino Sacramento" - foi determinada pelo governador e capital-general do Estado e, dirigindo-se pelas ruas, a procissão era guarnecida por dois regimentos militares. Estiveram presentes o capitão-general, o cabido, o clero, as comunidades religiosas, ordens terceiras, irmandades, confrarias e uma grande multidão (AHU, loc. cit.). Em 4 de fevereiro de 1772, o próprio José de Abranches enviou missiva ao Conselho Geral (anexada aos autos da culpa) pelo familiar do Santo Ofício Antônio de Souza Ferreira (cirurgião do navio Santa Ana e São Francisco Xavier) e, sob o comando do capitão Bernardo Franco, Joana Maria foi conduzida à Inquisição de Lisboa.

Ao desembarcar no Reino, em 29 de março de 1772, Joana foi imediatamente levada para os cárceres da custódia no Palácio dos Estaus. Nada trouxera consigo, apenas duas blusas, segundo o registro do alcaide Antônio Batista. Contudo, a criminada permaneceria incomunicável pelos próximos nove meses e só seria ouvida na Mesa a 10 de janeiro de 1773. Naquela manhã (na Casa Terceira das Audiências), perante o inquisidor José Joaquim Justiniano Mascarenhas Castelo Branco, Joana Maria entre lágrimas fez uma longa confissão. O inquisidor iniciou a 


\section{HISTÓRIA \\ MUNDO LUSO BRASILEIRO: RELAÇÕES DE PODER E RELIGIÃO}

sessão dizendo que a jovem fazia bem em estar ali, pois tinha a oportunidade de descarregar sua consciência e dar bom encaminhamento à sua causa.

Após fazer o juramento dos Evangelhos, prometendo dizer a verdade, Joana relatou que era natural da vila de Oeiras (patriarcado de Lisboa) e que, quando criança, para não passar fome foi trabalhar em casas de famílias. Aos 14 anos, morando no recolhimento de Santa Maria Madalena, foi dada em casamento a Francisco Antônio. Seis meses após o matrimônio, partiram para a cidade de Belém (capital do Grão-Pará), quando começou o seu calvário. Experimentou muitos maus tratos do marido e era espancada quase todos os dias. Mudaram-se depois para a Vila Vistosa da Madre de Deus quando, estando o marido ausente, aconteceu uma desgraça: furtaram dois frangos do quintal de sua casa. Sabendo que certamente seria espancada pelo marido e, apavorada, dormiu aquela noite na rua. No dia seguinte, procurou o cura na Igreja Matriz e, em confissão, deu-lhe conta do que se passava. Padre João Romeiro a aconselhou que "voltasse para a casa do seu marido e sofresse com paciência a má vida que levava".

Um relato dramático, sem dúvida. No entanto, dois detalhes chamam a atenção: a violência do marido e a indiferença do pároco - resultados da misoginia então dominante. Na sociedade de Antigo Regime era, absolutamente, natural que o marido batesse na mulher para corrigi-la; a esposa era um fardo na vida do homem. Parafraseando Salomão, Raphael Bluteau (1728) afirmou que: "entre mil homens achará um bom; entre todas as mulheres nenhuma boa". Segundo Vainfas (2014, p. $165 ; 175)$, muitos maridos faziam da pancada o principal meio de resolver as querelas domésticas; "visava-se a mulher como um ser diabólico, 'beata fingida', ruína de todos os homens que por ela se perdesse. Ao infeliz marido [...] só restava meter-Ihe muita pancada, 'parti-la ao meio', 'quebrar-lhe um braço', 'acabar-lhe a vida num momento'”.

Qualquer problema que ocorresse no lar, a culpa seria sempre da mulher. Isso explica o pavor de Joana ao fugir de casa e tentar encontrar no pároco uma autoridade que Ihe defendesse. Desapontada, com a indiferença do religioso, pensou num meio de escapar das mãos do marido:

Pôr em prática a intenção que tinha antes da confissão; que se furtar a partícula consagrada que lhe distribuíssem na mesa da comunhão, 


\section{HISTÓRIA}

\section{MUNDO LUSO BRASILEIRO: RELAÇÕES DE PODER E RELIGIÃO}

com o fim de fazer ela mesma depoente manifestar o seu delito para que a prendessem e enviassem para o Santo Ofício e por este modo apartar-se do poder do seu marido [...]. No mesmo dia, que foi o $3^{\circ}$ ou o $4^{\circ}$ do mês de novembro de 1771 , e como não estava outra pessoa que comungasse na mesma mesa, se voltou o sacerdote logo para o altar e ela depoente lançou a partícula consagrada que tinha recebido em sua boca e a envolveu em uma ponta de um lenço de algodão da Índia que tinha sobre a cabeça e se demorou no mesmo altar, [...] sendo que ninguém percebeu o sacrílego desacato que tinha feito ela depoente. E depois de acabar a missa, saiu ela da igreja e apanhou uma folha de uma árvore e nesta envolveu a sagrada [espécie] que estava um pouco umedecida de saliva da boca (ANTT, IL, proc. 9.802, fls. 70-71).

Em seguida, Joana relatou que se dirigiu à casa do capitão Domingos Pinto e, encontrando uma menina na sua porta, Ihe entregou a folha (em que estava envolvida a hóstia) e pediu que oferecesse a dona da casa para comprar aquela relíquia do Santo Lenho. Como D. Maria - após prometer quatro vinténs - desistiu da compra, Joana procurou outra conhecida chamada Francisca e pediu-lhe um pedaço de papel para envolver a partícula. Lançou a folha da árvore numa fogueira que encontrou pelo caminho alegando que se a jogasse no chão poderia ser pisada por qualquer pessoa e não queria que "fosse pisada uma folha em que estivera Nosso Senhor".

Depois foi à casa de Maria Teresa e lhe contou todo o sucedido "e as aflições que sentia seu coração". Assustada com a revelação, Maria Teresa chamou outra vizinha e ambas decidiram mandá-la embora, sem ficar com a partícula que gostaria que fosse devolvida ao pároco. Quando Joana se dirigia à igreja (para devolver a hóstia ao sacrário), as mulheres relataram o caso ao sargento-mor D. João Henriques, que passava pela rua, e a sequência dos acontecimentos nós já conhecemos. Numa primeira leitura, o relato é confuso e parece improvável. Seria, de fato, possível que Joana cometesse um sacrilégio contra a Eucaristia para ser enviada presa à Inquisição? Todavia, conhecemos outras tramas similares: dois indivíduos que praticaram crimes sob jurisdição inquisitorial para serem remetidos ao Santo Ofício na perspectiva de alcançar um futuro menos penoso.

Em 1726, na povoação de São Lourenço da Mata (bispado de Pernambuco), o artesão Manoel Fernandes dos Santos (20 anos), casado com Leonor da Cunha, cometeu um homicídio e foi levado para a cadeia da vila de Santo Antônio do Recife. 


\section{HISTÓRIA \\ MUNDO LUSO BRASILEIRO: RELAÇÕES DE PODER E RELIGIÃO}

Após 12 anos preso e sem esperança de liberdade, ao tomar conhecimento (por transmissão oral) que o crime de sodomia pertencia ao foro inquisitorial, decidiu praticá-lo com o prisioneiro Daniel Pereira por - segundo ele mesmo afirmou "entender que sabendo-se deste crime seria trazido preso para esta Inquisição aonde teria melhor livramento e [...] escaparia também da morte que temia". A denúncia chegou aos ouvidos do bispo de Olinda, D. Frei Luís de Santa Teresa, que em 1747 o remeteu aos Estaus. Depois de processado, o artesão ouviu sua sentença no auto de 1748 , foi açoitado publicamente e degredado às galés por dez anos. Todavia, contrariando sua sentença, Fernandes dos Santos conseguiu fugir das galés em maio de 1751 (ANTT, IL, proc. 11.607, fls. 15-17v; 39-48).

O segundo caso é do soldado Jakob Hiniger, natural de Osenbach na Alsácia (Alemanha). Quando criança foi batizado e crismado na religião católica. Depois de passar pela França e Espanha; foi morar em Portugal, na vila de Alenquer (em 1753), onde cometeu um homicídio e roubo, sendo preso no aljube secular. $\mathrm{Na}$ cadeia, se fez passar por luterano sendo "batizado pelas grades da prisão". Em seguida, foi enviado ao cárcere do Limoeiro (Lisboa), permanecendo como católico. Ao fugir do Limoeiro, foi capturado e preso a ferros e correntes. Desolado, declarouse luterano: "desprezando e não observando os preceitos da Igreja", deixando de jejuar, ouvir missa, confessar e comungar e não adorando a Eucaristia por muito anos; além de proferir "blasfêmias e palavras torpes". Tudo isso para - conforme ele mesmo confessou - ser enviado à Inquisição e "evitar a pena de morte". Foi denunciado e preso nos cárceres inquisitoriais em 1768 e, depois de um longo processo, em 1780 (aos 51 anos de idade), foi sentenciado: Abjuração de levi suspeita na fé, penitências espirituais e pagamento das custas (ANTT, IL, proc. 1.482, fls. 37-38; 44-82v).

Como se observa, Joana Maria não foi a primeira pessoa a cometer um delito de foro inquisitorial para, na esperança de alcançar outra perspectiva de futuro, dar um novo rumo a sua vida. Entretanto, a questão que persiste é a seguinte: por que Joana concebeu um plano tão esquisito e ousado? Por que profanar a hóstia consagrada? Seguramente o desespero das circunstâncias - a notícia de que seu marido a aguardava em casa com uma faca - contribuiu para isso. Contudo, o que garantiria que ela realmente seria enviada para o Tribunal da Inquisição? O caso era 


\section{HISTÓRIA \\ MUNDO LUSO BRASILEIRO: RELAÇÕES DE PODER E RELIGIÃO}

gravíssimo, mas, em tese, poderia ser julgado em âmbito local pela justiça eclesiástica. Nada garantia que Joana seria remetida a Lisboa. A não ser que houvesse um precedente. E, de fato, houve.

Na manhã do dia 12 de dezembro de 1770, portanto, há quase um ano do sacrilégio cometido por Joana, compareceu perante o inquisidor José de Abranches o familiar do Santo Ofício Manuel Álvares Chaves para fazer uma grave denúncia. Tinha poucas horas, o escravo Francisco da Costa Xavier (cativo do sargento-mor Manuel Joaquim de Sousa Feio), havia comungado na igreja do convento de Nossa Senhora das Mercês e "extraído da boca a sagrada [partícula], que envolta em um papel lhe fora mostrar à sua casa, perguntando-lhe: se o que tinha feito obrara mal. Dando por fundamento para tão sensível desacato: que lhe diziam, [existirem] dois deuses, e que queria ver com os seus próprios olhos a Nosso Senhor Jesus Cristo na sua mão" (AHU, Pará, Cx. 66, doc. 5.724). Imediatamente, Manuel Álvares prendeu o escravo e procurou o frade Manuel Inácio da Maia para confirmar se havia conferido a sagrada comunhão ao cativo. Após a confirmação, Manuel Álvares depositou a partícula (ainda umedecida) num "copo de vidro cristalino", e a devolveu ao frade que a recolheu no sacrário.

A notícia do sacrilégio espalhou-se rapidamente por toda a região. O escravo foi levado ao aljube eclesiástico e, após diligências iniciais, no dia $1^{\circ}$ de março de 1771, Francisco da Costa Xavier foi enviado ao Tribunal do Santo Ofício. ${ }^{54}$ Seguramente, Joana Maria ouviu esses relatos em Vila Vistosa. Nesse contexto - de dois sacrilégios à Eucaristia em menos de um ano -, o envio de Joana à Inquisição tornava-se urgente; para servir de exemplo aos fiéis e inibir novas ofensas ao Santíssimo Sacramento. Logo, pressupomos que ao planejar o desacato, Joana dava por certo seu retorno a Lisboa para - conforme disse - livrar-se do marido.

No dia 12 de março de 1773, Joana foi chamada à Mesa para conhecer seu curador, o padre Clemente Xavier dos Santos, que deveria orientá-la a confessar e não esconder seus crimes. Em seguida, na condição de ré, foi levada aos cárceres secretos. Passados uns dias, ocorreu a sessão de genealogia: declarou-se casada com o genovês Francisco Antônio Columa (serrador de madeira), natural da vila de

\footnotetext{
${ }^{54}$ A 29 de setembro de 1771, Francisco da Costa Xavier foi sentenciado: abjuração de levi suspeita na fé, açoites citra sanguinis effusionem, degredo de 10 anos para as galés e penitências espirituais (ANTT, IL, proc. 719).
}

REHR | Dourados, MS | v. 13 | n. 25 | p. 76-92 | Jan. / Jun. 2019 


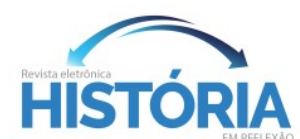

\section{MUNDO LUSO BRASILEIRO: RELAÇÕES DE PODER E RELIGIÃO}

Oeiras e moradora na Vila Vistosa da Madre de Deus (Pará). Seus pais eram, Lucas João e Maria do Rosário; não conhecia seus avós paternos ou maternos. Era batizada, mas não foi crismada. Costumava ir à igreja, ouvir missa, confessar e comungar. No exame de doutrina, de joelhos, recitou as principais orações cristãs, os sacramentos, os Mandamentos da Lei de Deus e os Igreja.

Parece que de fato Joana era uma cristã devota, inclusive pelo cuidado que teve com a folha na qual envolveu a partícula consagrada - preferiu queimá-la para que não foi pisoteada pelos homens. É, sobretudo, na sessão in genere que a ré demonstra sua reverência ao Santíssimo Sacramento. Ademais, as perguntas formuladas pelo inquisidor Castelo Branco externam sua crença e respeito à doutrina da transubstanciação. Esse dogma impõe que os fenômenos sensíveis (cor, sabor, odor) não se desfazem, no entanto, ao lado dessa aparência ocorre a experiência de uma mudança radical da substância do pão e do vinho consagrados. Segundo o chamado "mistério da transubstanciação", pelas palavras da consagração na missa, se efetua a conversão de toda a substância do pão (na substância do corpo de Cristo) e de toda a substância do vinho (na substância do sangue de Cristo). As aparências permanecem, mas a substância é Jesus Cristo (cf. REDONDI, 1991, p. 227-252).

Quadro 2: Síntese da sessão in genere da ré Joana Maria (16 de junho de 1773)

\begin{tabular}{|l|l|}
\hline \multicolumn{1}{|c|}{ Inquirição } & Resposta \\
\hline $\begin{array}{l}\text { Por algum tempo se apartou da Santa Fé Católica } \\
\text { ou deixou de crer em algum dos seus artigos e } \\
\text { mistérios? }\end{array}$ & Não. \\
\hline $\begin{array}{l}\text { Duvidou, por algum tempo, dos Sacramentos da } \\
\text { Igreja? }\end{array}$ & Não. \\
\hline $\begin{array}{l}\text { Sabe que os Sacramentos da Igreja foram } \\
\text { instituídos por Nosso Senhor Jesus Cristo para a } \\
\text { salvação das almas e que comunicam a graça aos } \\
\text { que dignamente os recebem? Sabe que um deles é } \\
\text { a Santíssima Eucaristia? }\end{array}$ & \\
\hline $\begin{array}{l}\text { Sabe que a Hóstia Consagrada é em realidade o } \\
\text { Corpo, Sangue, Alma e Divindade de Jesus Cristo, } \\
\text { tão verdadeiramente como está no céu? }\end{array}$ & \\
\hline $\begin{array}{l}\text { Sabe que em virtude das palavras da consagração } \\
\text { a Hóstia se transforma no Corpo de Cristo? }\end{array}$ & Nunca duvidou dessa verdade. \\
\hline $\begin{array}{l}\text { Sabe que o corpo de Cristo se conserva nas } \\
\text { espécies sacramentais, enquanto estas não se }\end{array}$ & Nunca duvidou dessa verdade. \\
\hline
\end{tabular}

REHR | Dourados, MS | v. 13 | n. 25 | p. 76-92 | Jan. / Jun. 2019 


\section{HISTÓRIA}

MUNDO LUSO BRASILEIRO: RELAÇÕES DE PODER E RELIGIÃO

\begin{tabular}{|l|l|}
\hline corrompem? & \\
\hline $\begin{array}{l}\text { Faltou algum tempo à veneração e respeito que } \\
\text { confessa ao Santíssimo Sacramento. }\end{array}$ & $\begin{array}{l}\text { Nunca deixou de adorar e reverenciar a } \\
\text { Eucaristia. Mesmo o desacato que tem } \\
\text { confessado nesta Mesa, foi por miséria e } \\
\text { infelicidade sua, desejando livrar-se dos } \\
\text { maus tratos que sofria do marido e que, } \\
\text { por isso, chora sentidas lágrimas de } \\
\text { arrependimento. }\end{array}$ \\
\hline $\begin{array}{l}\text { Ouviu de alguma pessoa que fazendo tal } \\
\text { sacrilégio, conseguiria se livrar do seu marido e e } \\
\text { nunca mais voltar para ele? }\end{array}$ & $\begin{array}{l}\text { Não. Só o Demônio que é autor de todas } \\
\text { as culpas foi quem lhe incitou o tal } \\
\text { desacato, que cometeu na esperança de } \\
\text { vir a esta Mesa confessar o seu delito e } \\
\text { pedir perdão dele. Tinha, contudo, } \\
\text { consciência da gravidade do delito e dos } \\
\text { castigos que poderia sofrer. }\end{array}$ \\
\hline
\end{tabular}

ANTT, IL, proc. 9.802, fls. 76-79v.

Passaram-se oito meses, sem que Joana tivesse notícia alguma do andamento de sua causa. A 23 de fevereiro de 1774, a ré voltou à Mesa para a sessão in specie e declarou que não tinha mais culpas a confessar. A Mesa, por sua vez, estava convencida de que o sacrilégio cometido não fora pelos motivos que alegava, "mas por sentir mal da Santa Fé Católica", dos sacramentos e, sobretudo, da Santíssima Eucaristia. No dia 10 de março, por ocasião da publicação do libelo acusatório, o promotor do Santo Ofício exigiu que a ré fosse "castigada com as maiores e mais graves penas do Direito que por suas culpas merece". Todavia, não indicou tais penas que ficaram a cargo da Mesa inquisitorial. Não deixa de ser curioso que o promotor não tenha indicado um castigo para a ré; o que era de praxe no libelo. Na sequência, o promotor fez a publicação da Prova da Justiça, ou seja, a leitura das denúncias do sumário remetido pelo ordinário do Pará. Ao término, Joana declarou que não tinha procurador nem contraditas em sua defesa; reconheceu seus erros e implorou misericórdia.

Oito dias depois, a Mesa fez conhecer o seu juízo: abjuração de vehementi suspeita na fé; açoites pelas ruas públicas (citra sanguinis effusionem); penitências espirituais e instrução ordinária; degredo de 10 anos para a Casa da Correção e pague às custas do processo. No mesmo dia, o Conselho Geral deu parecer favorável ao cumprimento da pena, afirmando que a ré foi bem julgada pelos inquisidores. O acórdão foi publicado em auto de fé privado a 22 de março de 1774 . 


\section{HISTÓRIA}

MUNDO LUSO BRASILEIRO: RELAÇÕES DE PODER E RELIGIÃO

$\mathrm{Na}$ ocasião, Joana assinou o termo de segredo comprometendo-se a nada revelar sobre o que viu e ouviu enquanto esteve nos Estaus.

Imagem 1: Termo de Abjuração

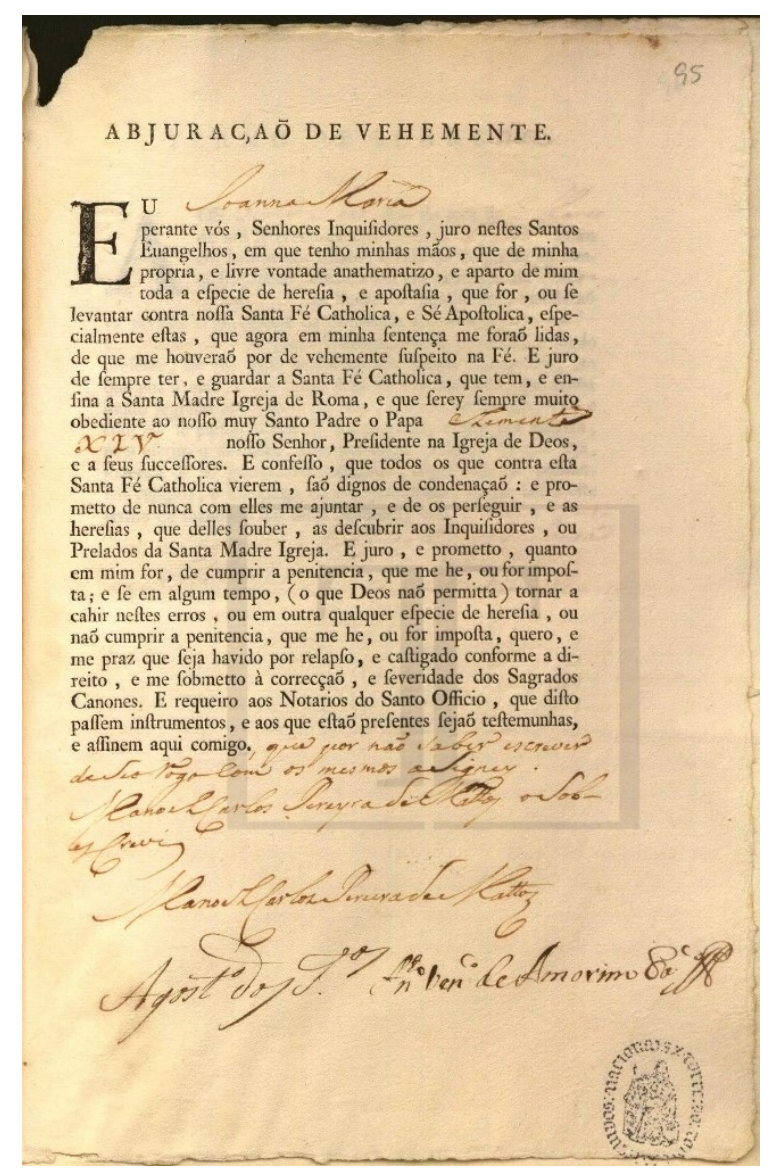

Imagem 2: Termo de Segredo

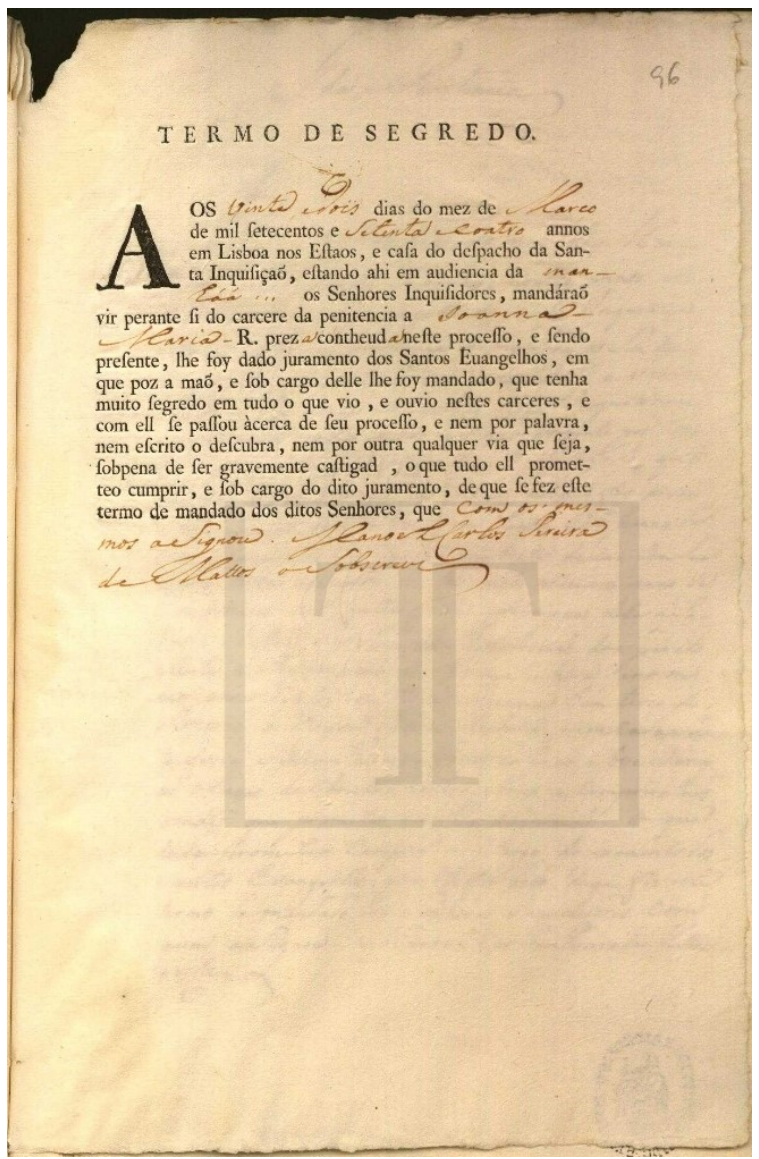

ANTT, IL, proc. 9.802, fls. 95-96.

Logo no dia seguinte, 23 de março de 1774, Joana assinou o "Termo de Ida e Penitência", pelo qual foi entregue à Justiça civil para a execução dos açoites públicos e, na sequência, ser conduzida à Casa da Correção. Na ocasião, foi-Ihe dito que penitências deveria cumprir: no primeiro ano de sentença, se confessará nas quatro principais festas do ano: Natal do Senhor, Páscoa da Ressurreição, Pentecostes e Assunção de Nossa Senhora; no mesmo período rezará em cada semana um terço do Rosário da Virgem Maria e em cada segunda-feira cinco vezes o Pai-Nosso e a Ave-Maria às chagas do Cristo Crucificado e cumprirá tudo o mais que prometeu em sua abjuração. Joana, resignada, tudo prometeu cumprir sob juramento dos Santos Evangelhos. Enfim, estava reconciliada com a Igreja e, por 


\section{HISTÓRIA}

MUNDO LUSO BRASILEIRO: RELAÇÕES DE PODER E RELIGIÃO

mais paradoxal que possa parecer, depois de percorrer um caminho longo e espinhoso, conseguiu livrar-se dos maus tratos do marido.

\section{Referências}

\section{Fontes manuscritas}

ARQUIVO HISTÓRICO ULTRAMARINO, Pará, Cx. 66, doc. 5.724; Cx. 67, doc. 5.805 .

ARQUIVO NACIONAL DA TORRE DO TOMBO, Inquisição de Lisboa, proc. 210; 219 ; 222; 225; 719; 1.482; 2.691; 2.699; 2.703; 2.704; 2.705; 2.707; 9.802; 11.607; $12.894 ; 13.327$.

\section{Bibliografia}

BLUTEAU, Raphael. Verbete: Molher. In: Vocabulario Portuguez e Latino.

Coimbra: 1712-1728. Disponível em: < http://dicionarios.bbm.usp.br/pt$\mathrm{br} /$ dicionario/1/molher $>$. Acesso em 08.05.2018.

BRAGA, Isabel M. R. Mendes Drumond. Entre Portugal e o Brasil ao serviço da Inquisição: o percurso de Geraldo José de Abranches (1711-1782). In: VAINFAS, Ronaldo; SANTOS, Georgina Silva dos; NEVES, Guilherme Pereira das. Retratos do Império: trajetórias individuais no mundo português nos séculos XVI a XIX. Niterói: EdUFF, 2006.

CONCÍLIO ECUMÊNICO DE TRENTO. Sessão XIII, de 11 de outubro de 1551. Decreto sobre a Santíssima Eucaristia. Disponível em:

$<$ http://www.montfort.org.br/bra/documentos/concilios/trento/\#sessao13>. Acesso em: 08.05.2018.

LIVRO DA VISITAÇÃO DO SANTO OFÍCIO DA INQUISIÇÃO AO ESTADO DO GRÃO-PARÁ (1763-1769). Texto inédito e apresentação de José Roberto do Amaral Lapa. Petrópolis: Vozes, 1978.

MARCOCCI, Giuseppe; PAIVA, José Pedro. História da Inquisição portuguesa (1536-1821). Lisboa: A Esfera dos Livros, 2013.

REDONDI, Pietro. Galileu Herético. São Paulo: Companhia das Letras, 1991.

VAINFAS, Ronaldo. Trópico dos pecados: moral, sexualidade e Inquisição no Brasil. Rio de Janeiro: Civilização Brasileira, 2014. 